\title{
An Evaluation of Quantitative Audit Materiality of Corporate Philanthropy by Kenyan Listed Firms
}

\author{
James N Ndegwa ${ }^{1}$ \\ 1 Department of Accounting and Finance, School of Business and Economics, The Cooperative University of \\ Kenya, Kenya \\ Correspondence: James N Ndegwa, Department of Accounting and Finance, School of Business and Economics, \\ The Cooperative University of Kenya, Karen, Nairobi, Kenya. E-mail: jndegwa@cuk,ac.ke; \\ ndegwajam@gmail.com
}

Received: June 8, 2018

Accepted: June 23, 2018

Online Published: July 5, 2018

doi:10.5539/ijef.v10n8p84

URL: https://doi.org/10.5539/ijef.v10n8p84

\begin{abstract}
There is currently no regulatory body or organized civil rights group that monitors the materiality of the cost of corporate philanthropy (CP) which has created a gap that is being exploited by many corporates to make no or insignificant donations to the public which is a potential source of conflict between the society and corporates. The current research has imported the auditing concept of quantitative audit materiality and applied it in the field of CP to test the materiality or significance of corporate philanthropy by listed firms in Kenya during the year 2013 with intention to monitor the significance of corporate philanthropy by Kenyan corporates. Purposive sampling technique was employed to select 16 out of 62 listed firms in Kenya where there was cost of corporate philanthropy reported by the firms. Descriptive statistical analysis and paired samples t-test were employed to analyses for significant or materiality of corporate philanthropy. The overall findings indicated that Kenyan firms made immaterial corporate donations with respect to their profit before tax (PBT). The study thus recommends for enactment of regulations to govern the matter of corporate donations in Kenya.
\end{abstract}

Keywords: corporate philanthropy, quantitative audit materiality

\section{Introduction}

\subsection{Background of the Study}

Questions have arisen in the past as to whether corporates engage in CSR as a marketing gimmick or such corporates are genuinely interested in alleviating the suffering by local communities (Tarus, 2015). According to Friedman, (1970) the business of business is business and a major issue of concern is whether corporate social responsibility (CSR) is part of the business or should firms focus on their business without participating in CSR (Shapira, 2012). Corporate philanthropy (CP) or corporate donation refers to the monetary measurement of CSR (Corporate Watch Report, 2006).

It is argued that businesses participate in CSR to fostering good public relations reasons (Corporate Watch Report, 2006) by being good corporate citizens and contributing to the society to improve the quality of life. Corporate donors can derive pride amongst peers and the society. CSR activities also tend to enhance brand image, reduce production cost as a result of recycling of waste (Tsoutsoura, 2004). Governments are also happy with the CSR participating firms and this improves on the agency relationship between shareholders and Government (OECD, 2003). CSR participating, firms can also avoid paying taxes since charitable donations are tax deductible (KPMG, 2013/14). Firms also engage in CSR as a strategy to avoid regulation or as a strategy against anti-corporate activism (Nkwankwo, 2015).

Local community reaction to inadequate $\mathrm{CP}$ can be in the form of protests, road blockages, injury and even death threat to corporate workers. By not pacifying the local communities corporates can incur unnecessary costs including disruption of work especially senior staff spending time managing the conflict and even lawsuits (Davis \& Frank, 2014). Anti-corporate activism can be potentially devastating to a company as witnessed against Shell Oil company in Niger Delta that led to the death of Ken Saro Wiwa an environment and social activist who was fighting against exploitation of the oil resources of the Ogoni people who were poverty stricken despite oil being extracted from their lands (Corporate Watch Report, 2006; Nkwankwo, 2015). CSR activities are thus regarded as 
an important factor in pacifying local communities and minimizing unnecessary conflicts (Abuya, 2016).

There are arguments against CSR which is deemed as a costly signal that is not justifiable as it compromises the financial objective of the firm which is the maximization of the shareholder's value. Some schools of thought also believe that in a free society private firms should not participate in CSR as it is not their business, instead they should focus on generating profits as long as they do so in a competitive and corruption free environment (Shapira, 2012; Friedman, 1970). Managers may engage in profit sacrificing through CSR activities to satisfy their own charitable preferences at the expense of maximizing shareholders wealth (Shapira, 2012). It is also believed that private firms that engage in CSR, lack the skills and jurisdiction to participate in community welfare activities (Tsoutsoura, 2004). Most of the time, it is the CEOs who decide the CSR activities that firms will engage in regardless of the extent of community welfare skills that the CEOs possess (Shapira, 2012).

The major beneficiaries of CP in Kenya have been healthcare and educations sectors while the major beneficiaries of individual donations have been religious organizations. A prominent CP activity in Kenya is the 'wings to fly' programme by Equity Bank and Master Card which sponsors the education of children from poor backgrounds. Thousands of children from poor families and orphans are sponsored in good schools and universities globally in an effort to uplift them and their families and by doing so Equity Bank and Master Card firms gives back to the society.

There is a growing concern about the materiality or significance of CSR activities by firms. If CSR is not material then the society is being short changed and should petition the corporates for more participation. This is to ensure fair sharing of the firm's success with its surrounding society (Muthuri \& Gilbert, 2010). The concept of quantitative audit materiality has the potential of providing a measure of the adequate level of CSR and hence minimize conflicts between corporates and communities that surround these corporates.

\subsection{Motivation of the Study}

The measurement of the adequacy of CP in the developing countries in particular Kenya is discretional, unknown and unregulated (Muthuri \& Gilbert, 2010). The measurement of materiality of CP is unclear as seemingly financially immaterial CP actions may be mitigated by non-financial corporate donations in the form of emotional support of beneficiaries. Corporates in Kenya are expected to practice self-regulation with regard to corporate philanthropy and this provides them with an opportunity for corporates to make inadequate donations to local communities and hence the cause of conflict (Nkwankwo, 2015). There are schools of thought that regard CP as a costly signal that is not justifiable as it compromises the financial objective of the firm which is the maximization of the shareholder's value (Shapira, 2012). Other schools of thought are of the opinion that CP is an essential part of the business (OECD, 2003). By importing the concept of quantitative definition of audit materiality, there is the potential of measuring and hence monitoring the adequacy of cost of corporate philanthropy which is the motivation behind the current research.

\subsection{Research Objectives}

To assess whether the cost of corporate philanthropy by Kenyan listed firms is quantitatively material.

\subsection{Research Hypothesis}

H0: There is no significant difference between cost of corporate philanthropy by Kenyan listed firms and the quantitative materiality threshold of $5 \%$ of profit before tax.

\section{Literature Review}

\subsection{Legitimacy Theory}

This theory posits that organizations continually seek to operate within the bounds and norms of their respective societies. Organization legitimacy exists when an entity's value system is congruent with the value system of the larger social system which the entity is part of and when disparity occurs in the 2 value systems, there is a threat to the entity's legitimacy (Cuganesan, 2007). This theory is relevant to the current research as CSR and corporate philanthropy aims at corporate co-existence with the surrounding society.

\subsubsection{Audit Materiality}

As per International Standard on Auditing (ISA) 400 on Risk assessment and Internal Control, audit risk is defined as the risk of expressing an inappropriate audit opinion when financial statements are materially misstated this definition tilts towards Type II error which is the risk of failure to modify an audit opinion on financial statements that are materially misstated. Conversely, Type I error in auditing refers to the risk of modifying an audit opinion on financial statements that are not materially misstated. It is thus difficult to discuss the concept of audit risk without considering the concept of audit materiality (McKee \& Eilifsen, 2000). 


\subsubsection{Qualitative Materiality}

According to International Standard on Auditing (ISA) 320 on Audit Materiality, information is deemed as material or significant if its omission or misstatement can influence the economic decisions. This definition is deemed as qualitative as it does not specify thresholds for measurement of materiality but employs the discretion of the reviewer to assess materiality of an item. The discretionary qualitative materiality may be susceptible to bias of the reviewer and hence the need for quantitative materiality. In addition, the discretionary aspect of qualitative materiality makes the assessment of materiality very complex as it requires measurement of what will or not affect the decisions of a knowledgeable investor under the specific circumstances affecting the investor at that time (Brennan \& Gray, 2005).

\subsubsection{Quantitative Materiality}

In an effort to standardize measurement of materiality during audits and avoid the discretionary assessment, accountants for many years have employed a quantitative approach in materiality assessment and have used the "5\% rule" when assessing for indicators of materiality in financial statement item (Vorhies, 2005). The 5\% rule has been refined further and some accountants posit that as per quantitative materiality, an item is deemed to be material if exceeds $1 \%$ of the total assets or if it exceeds 5\% of PBT or if it exceeds 5\% of sales or if it exceeds $2 \%$ of total expenses (Horatiu, 2009). In this research, the cost of CP is assessed to be material of it exceeds 5\% of profit before tax or if it exceeds $2 \%$ of total expenses (Rittenberg et al., 2012). There is a plausible inverse relationship between the cost of $\mathrm{CP}$ and $\mathrm{PBT}$ and there is a plausible positive relationship between $\mathrm{CP}$ and total expenses. There is no clear plausible relationship between the cost of CP and sales or total assets.

Even in the bible the concept of tithe which means $10 \%$ appears to be consistent with the concept of quantitative audit materiality as both concepts provide thresholds for measuring the adequacy of donations and contributions. According to the old testament Christians were expected to give 10\% of their income to the church for the purpose of meeting the needs of foreigners, orphans and widows (Deuteronomy 26:12-13). The 10\% of income tithe requirement is very high compared to the quantitative audit materiality thresholds.

\subsubsection{Relative Materiality}

The susceptibility of qualitative materiality is further enhanced by the fact that as materiality is a relative term and what is material in one firm may be immaterial to another (Brennan \& Gray, 2005). This implies that what is regarded as material in a small entity may be immaterial in a large entity. However in auditing of financial statements, all fraud is deemed as material since the intention is the same regardless of the amount involved (Millichamp \& Taylor, 2012).

\subsubsection{Corporate Social Responsibility and Corporate Philanthropy}

CSR refers to firms achieving commercial success in ways that honor ethical values and respect people, communities and natural environment (Tsoutsoura, 2004). CSR is also concerned with governance, product safety, equal opportunities, human rights, community involvement and environment preservation (Tilt, 2010).

Corporate philanthropy $(\mathrm{CP})$ or corporate donations as a component of CSR refers to the charitable donations by firms of their profits and resources to charitable activities (OECD, 2003). Corporate philanthropy (CP) or corporate donations provides a monetary value to CSR (Corporate Watch Report, 2006).

Corporate philanthropy (CP) or corporate donations may be in the form of sales donations, cash donations, product donation, volunteering employee time, collection of customer donations, charity events, promotion of public service announcements amongst other related events (Okwemba et al., 2014). CP can be made directly by the corporation or through foundations created by the corporations. The establishment of private foundations may be for selfish reasons like to avoid taxes or may be for selfless reasons such as to aid charitable courses in the society (OECD, 2003). CP also involves explicit pro-social spending and donations to charitable institutions (Shapira, 2012).

\subsection{Empirical Literature Review}

According to Shapira (2012) companies in the USA spend on average about $\$ 16$ million on CSR activities which in relative terms amounts to about $1 \%$ of pre-tax profits. While in absolute terms the corporate donations may increase, in relative terms the corporate donations remain stable at $1 \%$ of the pre-tax profits. This implies that American companies fail to meet the quantitative materiality threshold of $5 \%$ of pre-tax profits by only contributing on average $1 \%$ to philanthropy. Ashfar (2012) studied corporate philanthropy in the UK and US and the impact on cycles, strategies and CEO succession. In the UK the study was carried out on an average sample of 220 firms over a 15 year period. The data collected for the study indicated that on average companies contributed 
$£ 2,974,000$ in corporate donations whereas the average pre-tax profits amounted to $£ 205,445,000$. This implied that corporate donations in the UK averaged $1.45 \%$ of profits before tax. Even though the Shapira (2012) and Ashfar (2012) studies aimed at measuring the relationship between CSR and profitability, they provided relevant data to facilitate the current research.

H1: There is a significant difference between cost of corporate philanthropy by Kenyan companies and the quantitative materiality threshold of 5\% for profit before tax.

\section{Research Methodology}

\subsection{Research Design}

This research employed an exploratory research design was employed in this research the assessment of quantitative materiality of corporate donations has not been researched upon in the past.

\subsection{Population and Sample}

There were 62 companies listed in the NSE as at $31^{\text {st }}$ December 2014. However CP disclosure being voluntary is very low among case Kenyan corporates and only 16 listed firms disclosed the amount they spent on CP in the year 2014 with the other firms chose to be secretive about the information.

\subsection{Data Collection}

Secondary data was employed in this research and a cross sectional approach was adopted where data was collected from annual reports of 16 sampled firms in year 2014 (Cresswell, 2014).

\subsection{Data Analysis}

The first research objective was assessed using descriptive statistics which involved the comparison of the cost of $\mathrm{CP}$ as a ratio of profit before tax (PBT) against the quantitative audit materiality threshold of $5 \%$ of PBT. Inferential statistics was also employed through the use of paired samples t-test to assess whether there was a significant difference between the cost of $\mathrm{CP}$ as a percentage of PBT and the quantitative materiality threshold of $5 \%$ of profit before tax (Horatiu, 2009).

The test of statistical significance of corporate philanthropy in terms of profit before tax was to be tested by employing one sample t-test which was computed as follows (Sweeney, 2006):

$$
T \text { statistic }=\bar{x}-\mu / S . E
$$

Where: $\mu=$ test value $=5 \%$

S.E $=$ standard error $=\sigma / \sqrt{ } \mathrm{n}$

$\sigma=$ standard deviation

$\mathrm{n}=$ number of items being tested

\section{Research Findings}

\subsection{Descriptive Statistical Analysis Findings}

\subsubsection{Descriptive Statistics on Materiality of CP When Related to Profits of Listed Firms}

As per Table 1 on descriptive statistics on quantitative materiality of corporate philanthropy cost as a ratio of profit before tax in Kenyan listed firms, only one firm out of the 16 sampled firms (which is a ratio of $6.25 \%$ ) had material corporate philanthropy cost when compared to profitability. This implies that most listed firms in Kenya neglect the materiality aspect of the corporate donations that they make which can contribute to underdevelopment of the Kenyan society.

Table 1. Descriptive statistics on materiality of $\mathrm{CP}$ when related to profits of listed firms

\begin{tabular}{ccccccc}
\hline S/N & Firm & $\begin{array}{c}\text { CP Ksh. } \\
\text { (Millions) }\end{array}$ & $\begin{array}{c}\text { PBT Ksh. } \\
\text { (Billions) }\end{array}$ & $\begin{array}{c}\text { Ratio of CP to } \\
\text { PBT (\%) }\end{array}$ & $\begin{array}{c}\text { Quantitative Materiality } \\
\text { Threshold (\%) }\end{array}$ & $\begin{array}{c}\text { Level of Materiality of } \\
\text { Corporate Philanthropy }\end{array}$ \\
\hline 1 & CO.1 & 315.8 & 34.98 & $\mathbf{0 . 9}$ & 5 & Not material \\
2 & CO.2 & 124 & 17.7 & $\mathbf{0 . 7}$ & 5 & Not material \\
3 & CO.3 & 122.5 & 8 & $\mathbf{1 . 5 3}$ & 5 & Not material \\
4 & CO.4 & 11.4 & 7.7 & $\mathbf{0 . 1 4 8}$ & 5 & Not material \\
5 & CO. 5 & 18.5 & 14.345 & $\mathbf{0 . 1 2 9}$ & 5 & Not material \\
6 & CO.6 & 26.4 & 7.134 & $\mathbf{0 . 3 7}$ & 5 & Not material \\
7 & CO.7 & 212.7 & 16 & $\mathbf{1 . 3 3}$ & 5 & Not material \\
\hline
\end{tabular}




\begin{tabular}{lcccccc}
\hline 8 & CO.8 & 65 & 2.251 & $\mathbf{2 . 8 9}$ & 5 & Not material \\
9 & CO. 9 & 555.3 & 16.089 & $\mathbf{3 . 4 5}$ & 5 & Not material \\
10 & CO.10 & 57 & 8.131 & $\mathbf{0 . 7}$ & 5 & Not material \\
11 & CO.11 & 60 & 1.779 & $\mathbf{3 . 3 7}$ & 5 & Not material \\
12 & CO.12 & 143.4 & 13.354 & $\mathbf{1 . 0 7}$ & 5 & Not material \\
13 & CO.13 & 135 & 1.213 & $\mathbf{1 1 . 1 2}$ & 5 & Material \\
14 & CO.14 & 180 & 8.521 & $\mathbf{2 . 1 1}$ & 5 & Not material \\
15 & CO.15 & 191 & 5 & $\mathbf{3 . 8 2}$ & 5 & Not material \\
16 & CO.16 & 42 & 5.127 & $\mathbf{0 . 8 2}$ & 5 & Not material \\
\hline
\end{tabular}

\subsection{Diagnostic Tests Findings}

As per Table 2 on normality test of the data, the results are that the data is generally normally distributed with p-values being greater than 0.05 at $95 \%$ level of confidence. The implication of these findings is that the data was suitable for parametric tests.

Table 2. Normality test findings

\begin{tabular}{lccccc}
\hline One-Sample Kolmogorov-Smirnov Test & & & & & \\
\hline & CP & PBT & RATIO1 & EXPENSES & RATIO2 \\
N & 16 & 16 & 16 & 16 & 16 \\
Asymp. Sig. (2-tailed) & $\mathbf{. 6 6 9}$ & $\mathbf{4 4 4}$ & $\mathbf{. 3 9 1}$ & $\mathbf{. 0 2 5}$ & $\mathbf{. 4 8 2}$ \\
\hline
\end{tabular}

Table 3. Breusch-godfrey serial correlation LM test

\begin{tabular}{cc}
\hline F-statistic & Obs*R-squared \\
0.30362 & 1.01131 \\
Probability & Probability \\
0.74541 & 0.60311 \\
\hline
\end{tabular}

As per Table 3, there was no presence of serial correlation problem in the data as the p-values were greater than 0.05 level at $95 \%$ level of significance the null hypothesis for the test being lack of significant serial correlation in the data.

Table 4. White heteroskedasticity test findings

\begin{tabular}{cc}
\hline F-statistic & Obs*R-squared \\
1.76624 & 10.6995 \\
Probability & Probability \\
0.23395 & 0.21932 \\
\hline
\end{tabular}

As per Table 4, there was no presence of heteroscedasticity problem in the data as the p-values were greater than 0.05 level at $95 \%$ level of significance the null hypothesis for the test presence of homoscedasticity in the data.

Table 5. Multicollinearity test findings

\begin{tabular}{lcc}
\hline & \multicolumn{2}{c}{ Collinearity Statistics } \\
\cline { 2 - 3 } Variables & Tolerance & VIF \\
\hline PBT & .392 & 2.550 \\
RATIO 1 & .312 & 3.206 \\
EXPENSES & .418 & 2.395 \\
RATIO 2 & .323 & 3.094 \\
\hline
\end{tabular}

As per Table 5 the data lacked the problem of multicollinearity as the value inflated factors (VIF) were all below the threshold of 10 .

\subsection{Corporate Philanthropy Paired Samples T-Test Findings}

The findings of the one sample t-test also indicated a p-value of 0.001 which implied that there was a significant 
difference between corporate philanthropy cost as a percentage of profit before tax and the quantitative materiality threshold of $5 \%$ of profit before tax as per Table 6 . The null hypothesis that there is no significant difference between corporate donations by Kenyan listed firms and the quantitative materiality threshold of 5\% of pre-tax profits was thus rejected. These findings thus implied that the Kenyan listed firms were not donating adequately to the Kenyan society.

Table 6. Corporate philanthropy paired samples T-test findings

\begin{tabular}{|c|c|c|c|c|c|c|}
\hline \multicolumn{7}{|c|}{ One-Sample Test } \\
\hline & \multicolumn{6}{|c|}{ Test Value $=5$} \\
\hline & \multirow[t]{2}{*}{$\mathrm{t}$} & \multirow[t]{2}{*}{ df } & \multirow[t]{2}{*}{ Sig. (2-tailed) } & \multirow[t]{2}{*}{ Mean Difference } & \multicolumn{2}{|c|}{ 95\% Confidence Interval of the Differenc } \\
\hline & & & & & Lower & Upper \\
\hline $\mathrm{CP}$ & -4.243 & 15 & .001 & -2.84644 & -4.2762 & -1.4166 \\
\hline
\end{tabular}

\subsection{Overall Findings}

As per the results from descriptive statistics and paired samples t-test, the overall findings indicate that companies listed in the NSE do not make significant contribution towards CSR as per the definitions and thresholds provided in quantitative audit materiality (Horatiu, 2009).

\section{Discussions, Conclusions and Recommendations}

\subsection{Discussions}

The findings of the current research indicated that generally, Kenyan listed companies do not contribute materially towards CSR activities. These findings are consistent with those of Shapiro (2012) who also found that on average, companies in the USA do not contribute materially towards CSR activities as the corporate donations constitute $1 \%$ of pre-tax profits which is below the materiality threshold of $5 \%$ of pre-tax profits (Horatiu, 2009).

\subsection{Conclusion}

From the findings, many corporates in Kenya appear not make material or adequate donations to the Kenyan society despite being heavily dependent on the society for their survival (Muthuri \& Gilbert, 2010). The inadequate $\mathrm{CP}$ can be attributed to the fact that there is no regulatory requirement that requires corporates to give back to the society in a manner that is can be clearly monitored. In the absence of a regulatory framework, the quantitative audit materiality thresholds of $5 \%$ of profit before tax (Horatiu, 2009) can be employed as a potential measure of adequacy of $\mathrm{CP}$ to the society and hence prevent potential conflict from arising between the society and corporates.

\subsection{Policy Implications and Recommendations}

The insignificant contribution to the Kenyan society by corporates makes the society suffer from under development at the expense of corporates, some of whom are international and hence have the potential of repatriating the excess profits to their home country. There is thus need for regulatory bodies to consider enacting regulation and perhaps accounting standards that require clear disclosure on $\mathrm{CP}$ spending in the financial statements to enable monitoring.

\subsection{Suggestions for Further Studies}

Similar research can be carried out in other markets and different quantitative materiality threshold can be employed for comparison purpose.

\section{References}

Abuya, W. (2016). Mining conflicts and Corporate Social Responsibility: Titanium mining in Kwale, Kenya. https://doi.org/10.1016/j.exis.2015.12.008

Ashfar, T. (2012). Corporate Philanthropy in the UK and US: The Impact of Cycles, Strategies and CEO Succession. Unpublished PhD Dissertation, London School of Economics and Political Science. Retrieved from https://core.ac.uk/download/pdf/5890884.pdf

Branco, C. M., \& Rodrigues, L. L. (2007). Positioning Stakeholder Theory within the debate of CSR. Electronic Journal of Business Ethics and Organizational Studies, 12(1).

Brennan, N., \& Gray, J. S. (2005). The Impact of Materiality: Accounting's Best Kept Secret. Asian Academy of 
Management Journal of Accounting and Finance, l(1). Retrieved from http://www.irserver.ucd.ie/.../10197/.../04_17\%20Brennan\%20Gray\%20The\%20Impact\%20of\%2..

Corporate Watch Report. (2006). What's wrong with corporate social responsibility? Retrieved from https://corporatewatch.org)...>

Creswell, J. W. (2014). Research Design: Quantitative, Qualitative and Mixed Methods Approach (4th ed.). Washington DC, USA: SAGE Publishers.

Cuganesan, S. (2007). Legitimacy Theory: A Story of Reporting Social and Environmental Matters within the Australian Food and Beverage Industry. Presented to the 5th Asian Pacific Interdisciplinary Research in Accounting (APIRA) Conference, 8-10 July 2007, Auckland, New Zealand. Retrieved from https://ssrn.com/abstract=1360518

Davis, R., \& Frank, D. (2014). Costs of Company-Community Conflict in the Extractive Sector. CSR Initiative at the Harvard Kennedy School Report No. 66. Cambridge, MA: Harvard Kennedy School. Retrieved from https://sites.hks.harvard.edu/.../CSRI/.../Costs\%20of\%20Conflict_Davis\%20\%20Franks

Deuteronomy 26:12-13. (1995). Parents Resource Bible. Wheaton, Illinois, USA: Tyndale House Publishers. Retrieved from https://www.rts.edu/sharedresources/documents/global/.../201110-Hartman-Aaron.pdf

Drucker, P. (1989). The New Realities. NY, NA: Harper \& Row. Retrieved from https://www.amazon.com/New-Realities-Peter-Drucker/dp/0765805332

Freeman, R. E., Harrison, J. S., Wicks, C. A., Parmar, B. L., \& Colle, S. (2010). Stakeholder Theory: The State of the Art. NY, NA: Cambridge University Press. https://doi.org/10.1017/CBO9780511815768

Friedman, M. (1970). The Social Responsibility of Business is to Increase Profits. NY Times Magazine. Retrieved from http://www.nytimes.com/1970/.../a-friedman-doctrine-the-social-responsibility-of-business-i...

Kipruto, D. (2014). The Effect of Corporate Social Responsibility on Financial Performance of Commercial Banks in Kenya (pp. 54-55). Unpublished MBA project, UoN. Retrieved from http://www.chss.uonbi.ac.ke/sites/.../KIPRUTO\%20Daniel\%20MSc\%20Finance\%20Project.pd

Kotler, P., \& Lee, N. (2005). Corporate Social Responsibility: Doing the Most Good for Your Company and Your Cause. NJ, NA: John Wiley and Sons. Retrieved from https://www.amazon.com/Corporate-Social-Responsibility-Doing-Company/.../047147...

KPMG. (2013/14). Kenya Fiscal Guide. Retrieved from https://assets.kpmg.com/content/dam/kpmg/ke/pdf/tax/kenya-budget-brief-2014.pdf

Mbithi, A. M. (2015). Effects of Corporate Social Responsibility on Organizations' Profitability of the Banks Listed on Nairobi Stock Exchange (pp. 28-37). Unpublished MBA project, South Eastern Kenya University. Retrieved from http://www.erepository.uonbi.ac.ke/../Gichohi_Effects\%20of\%20Corporate\%20Social\%20Respo

McKee, \& Eilifsen. (2000). Current Materiality Guidelines for Auditors. Working Paper No. 51/00, SNF project No.7844, Foundation for Research in Economic and Business Administration, Norwegian Research Council. Retrieved from https://brage.bibsys.no/xmlui/bitstream/handle/11250/166032/A51_00.pdf?...1

Millichamp, A., \& Taylor, R. (2012). Auditing (10th ed.). Cengage Learning EMEA, UK. Retrieved from https://www.amazon.com/Auditing-Alan-Millichamp/dp/1408044080

Muthuri, J. N., \& Gilbert, V. (2010). An Institution Analysis of Corporate Social Responsibility in Kenya, Journal of Business Ethics, 98, 467-483. https://doi.org/10.1007/s10551-010-0588-9

Nairobi Securities Exchange. (2012-2013). NSE Handbook. Retrieved from https://africanexchanges.org/sites/default/files/publications/nse_handbook.pdf

Neiheisel, S. R. (1994). Corporate Strategy and the Politics of Goodwill. Peter Lang, NY, NA. Retrieved from https://www.researchgate.net/.../259208482_Corporate_Philanthropy_Political_Influenc..

Nkwankwo, B. O. (2015). The Politics of Conflict over Oil in the Niger Delta Region of Nigeria: A Review of the Corporate Social Responsibility Strategies of the Oil Companies. American Journal of Educational Research, 3(4). Retrieved from https://journals.openedition.org/cea/1704?lang=en

OECD. (2003). Philanthropic Foundations and Development Cooperation. DAC Journal Off Print Version, 4(3). Retrieved from http://www.oecd.org/development/stats/22272860.pdf

Okwemba, M. E., Chitiavi, M. S., Egessa, R., Musiega, D., \& Musiega, G. M. (2014). Effect of Corporate Social 
Responsibility on Organizational Performance: Banking Sector in Kenya in Kakamega County. International Journal of Business and Management Invention, 3(4), 37-51. Retrieved from http://www.ijbmi.org/papers/Vol(3)4/Version-1/F0341037051.pdf

Rittenberg, L., Johnstone, K., \& Gramling, A. (2012). Auditing: A Business Risk Approach (8th ed.). South Western Cengage Learning, Mason, NA. Retrieved from https://digitalcommons.kennesaw.edu/facpubs/1325

Shapira, R. (2012). Corporate Philanthropy as a Signaling and Co-optation, Havard University John M. Olin Center for Law. Economics, and Business Fellows, Discussion Paper Series, No. 44. Retrieved from http://www.law.harvard.edu/programs/olin_center/fellows_papers/pdf/Shapira_44.pdf

Sweeney, D. J. (2006). Fundamentals of Business Statistics (pp. 552-553). International Students Edition, Thomson South Western Publishers, USA. Retrieved from https://www.amazon.com/Statistics-Business-Economics-7TH/dp/B004HP1I9Q

Tarus, D. K. (2015). Corporate Social Responsibility Engagement in Kenya: Bottom Line or Rhetoric? Journal of African Business, 16(3), 289-304. https://doi.org/10.1080/15228916.2015.1071998

Tilt, C. A. (2010). Corporate Responsibility Accounting and Accountants. Chapter 1, Springer Professional Perspectives on Corporate Social Responsibility, XVIII. Retrieved from https://www.springer.com/cda/content/document/cda.../9783642026294-c1.pdf

Tsoutsoura, M. (2004). Corporate Social Responsibility and Financial Performance. Haas Business School, University of California, U.S.A. Retrieved from https://escholarship.org/uc/item/111799p2

Vorhies, J. B. (2005). The Importance of Materiality. Journal of Accountancy, 199(5), 53. Retrieved from http://www.citeseerx.ist.psu.edu/viewdoc/download?doi=10.1.1.899.4546\&rep=rep1...

Wood, F. (2007). Business Accounting (Vol. 2, 10th ed.). Harlow, UK: Pearson's Publishers. Retrieved from https://www.amazon.co.uk/...Business-Accounting-MyAccountingLab.../0273759280

Wright, C. (2012). CSR/SRI CEO Briefing Report. African Investor Magazine. Retrieved from https://www.emeraldinsight.com/doi/full/10.1108/MF-12-2014-0307?fullSc=1

\section{Appendix 1. Names of the Sampled Listed companies}

\begin{tabular}{cc}
\hline $\mathbf{S} / \mathbf{N}$ & Listed Company \\
\hline 1 & Safaricom \\
2 & KCB Bank \\
3 & Cooperative Bank \\
4 & CFC Stanbic Bank \\
5 & Standard chartered bank \\
6 & EABL \\
7 & Barclays Bank \\
8 & Chase Bank \\
9 & Equity Bank \\
10 & I\&M Bank \\
11 & National Bank of Kenya \\
12 & Standard Chartered \\
13 & Housing Finance Bank \\
14 & Diamond Trust Bank \\
15 & National Industrial Credit \\
16 & CFC Bank \\
\hline
\end{tabular}

\section{Copyrights}

Copyright for this article is retained by the author(s), with first publication rights granted to the journal.

This is an open-access article distributed under the terms and conditions of the Creative Commons Attribution license (http://creativecommons.org/licenses/by/4.0/). 